\title{
Determination of Physicochemical Properties and Toxic Heavy Metals Levels in Honey Samples from West of Libya
}

\author{
A.S. Salama ${ }^{1}$, A.M. Etorki ${ }^{2}$, M.H. Awad ${ }^{1, *}$ \\ ${ }^{1}$ Department of Chemistry, Faculty of Arts and Sciences - Kasr Khiar, Al-Mergib University, Libya. \\ ${ }^{2}$ Department of Chemistry, Faculty of science, University of Tripoli, Libya.
}

\section{ART ICLE DET A I LS}

\section{Article history:}

Received 23 February 2019

Accepted 21 March 2019

Available online 16 April 2019

\section{Keywords:}

Bee Honey

Physicochemical Properties

Heavy Metals

Libya

\begin{abstract}
A B S T R A C T
This study was done to investigate the physicochemical properties of bee honey samples collected from different locations in west of Libya. The concentration of essential elements ( $\mathrm{Na}, \mathrm{K}$, and $\mathrm{Ca}$ ), and toxic heavy metals $(\mathrm{Pb}, \mathrm{Cd}, \mathrm{Hg}$, and $\mathrm{As})$ in honey samples were determined by flame photometer, and atomic absorption spectrometer. The results showed significant variation among the honey samples may be attributed to the plants floral types, which indicate that the mean values of moisture ranged from 20.6 to $25.1 \%$ was a slight higher than the Codex limit $20 \%$, pH mean values 4.12 to 4.74 , free acid equivalent 20 to $27 \mathrm{~m}$ eq. $/ \mathrm{kg}$, total dissolved substance 646 to $994 \mathrm{ppm}$, and specific conductivity 638.5 to 1004 $\mu \mathrm{S} / \mathrm{cm}$. The mean values of minerals concentration in $(\mathrm{mg} / \mathrm{kg}) \mathrm{such}$ as potassium were ranged from 1120.1 to 1980.6 , sodium 506.8 to 804.6 , calcium 923.92 to 1117.5 , lead 2.42 to 10.98 , cadmium 0.125 to 0.150 , mercury 0.021 to 0.10 , and arsenic 0.006 to 0.018 . The results revealed that the concentration of $\mathrm{Hg}$ and $\mathrm{As}$ in honey samples confine with the Codex range, on the other hand the study indicated that the concentration of $\mathrm{Pb}$ and $\mathrm{Cd}$ in honey confine with some international specifications and different with some others. The honey study may be useful for assessing the presence of environmental contaminants.
\end{abstract}

\section{Introduction}

According to the Codex [1], and National Honey Board [2], honey is dark golden a sweet, viscous fluid produced by Bees from the nectar of flowers and plant honeydew. The composition of bee honey is rather variable and primarily depends on the floral source, however, certain external factors also play a role in honey composition, such as environmental factors, seasonal and processing conditions, packaging and storage period. Normally honey contains 14.4 to $22 \%$ moisture, 40 to $50 \%$ fructose, 32 to $37 \%$ glucose, 0 to $2 \%$ sucrose, and less than $0.25 \%$ of ash [3].

Honey contains at least 181 substances such as free acids, numerous enzymes, vitamins in small amounts, various plant coloring materials, and trace elements such as $\mathrm{Fe}, \mathrm{Cu}, \mathrm{Zn}, \mathrm{Sn}$, etc. Honey is one of the most easily predigested foods. In Libya and many countries bee honey was and still used to preserve fruit and to make different types of cakes, sweetmeats and also it was and still a part of traditional medicine in many countries all over the world [4].

The mineral composition in bee honey is dependent on the natural absorption of elements by plants roots from the soil and the environment usually, the mineral content of honey participates to the color of the honey, which may change from light to dark, In fact, elements concentration in bee honey was found to be correlated with geographic and floral origins, geochemical soil composition and local contamination $[5,6]$. The most abundant cationic metals in honey are $\mathrm{K}, \mathrm{Na}, \mathrm{Ca}, \mathrm{Si}$, and $\mathrm{Mg}$ [7]. Trace elements such as $\mathrm{Al}, \mathrm{Mn}, \mathrm{Fe}, \mathrm{Cu}, \mathrm{Zn}$, and Se, and some toxic heavy metals as $\mathrm{Pb}, \mathrm{Cd}, \mathrm{Hg}$, and $\mathrm{As}$, may also present naturally or because of contamination by environmental sources [8,9]. These metals play an important and pivotal role in metabolism, health and disease. Their existing in human and animal food is very interesting, but if they exceed their safety levels, they well be toxic [10]. House [11], and Grigoryan et al. [12] reported that Bees undoubtedly do not collect minerals separately but collect them indirectly along with pollen, nectar and water, whereas Pollen is a rich source of minerals ranging from 2.9 to $8.3 \%$ [13].

\section{Experimental Methods}

Twenty-four honey samples were collected from eight locations in west of Libya (Fig. 1) and collected three samples from each locality. The bee honey samples collected were labeled (GR, BL, MS, RH, AB, AD, TC, and TE) for easy identification. All samples were stored in glass jars and kept in refrigeration at $4{ }^{\circ} \mathrm{C}$ until needed for the different analysis. All other chemicals used were of analytical reagent grade.

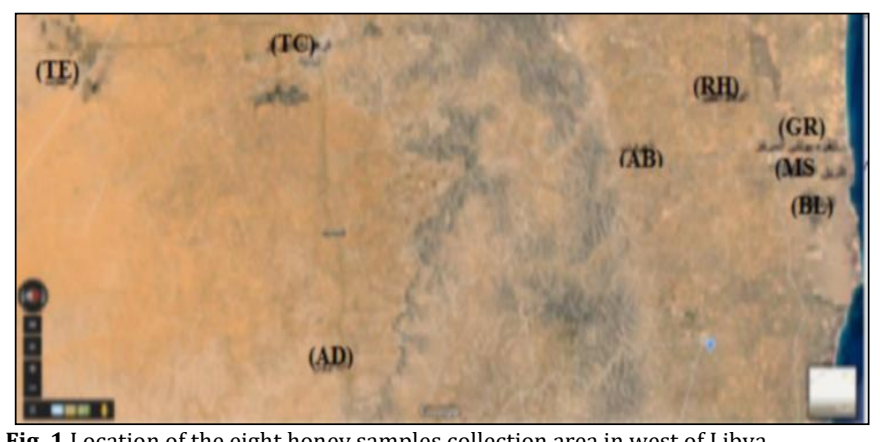

Fig. 1 Location of the eight honey samples collection area in west of Libya

\subsection{Physicochemical Analysis}

Moisture content was measured according to method cited by Eyobel et al. [14], the $\mathrm{pH}$ value of honey samples (20\%) were determined using a glass electrode $\mathrm{pH}$ meter (Jenway- Model 3505) according to the procedure cited by Olugbemi, [15]. The total acid equivalent values of all honey samples were determined by acid-base titration method [16]. Free acidity in $\mathrm{mEq} . / \mathrm{kg}$ of honey samples was calculated according to the following equation,

free acid equivalent $=[\mathrm{NaOH}(0.1 \mathrm{M}) \times \mathrm{V}(\mathrm{mL})] /[$ [ honey weight $(\mathrm{kg})]$

Electrical conductivity $(\mu \mathrm{S} / \mathrm{cm})$, and total dissolved substance (ppm) were determined using a conductivity meter (Jenway-Model 3545) for aqueous honey solution $(20 \% \mathrm{w} / \mathrm{v})$ at $25^{\circ} \mathrm{C}[14]$. 


\subsection{Mineral Content}

A $1.0 \mathrm{~g}$ of honey samples were weighted accurately in a vessel and then covered with its lid. A $6.0 \mathrm{~mL}$ of $\mathrm{HNO}_{3}(65 \%)$ were added and the mixture was allowed to stand at room temperature until initial reaction subsided and then $2.0 \mathrm{~mL}$ of $\mathrm{H}_{2} \mathrm{O}_{2}$ (30 vol.) were also added. The mixture was then transferred to the Milestone microwave unit after closing the vessel inside the rotator, and then the microwave program was started by setting the time and watt. The vessels were cooled and opened, then rinsed with deionized water three times in a beaker as well as beaker side. This solution was filtered in $25.0 \mathrm{~mL}$ volumetric flask and completed to the mark with deionized water, and transferred to a polyethylene container. Sodium, potassium, and calcium concentration were measured using a flame photometer (BWB Technologies, UK), while the toxic heavy metals concentrations were read using atomic absorption spectroscopy (Shimadzu AA 6701 F; A. A Spectrophotometer; Shimadzu Ltd, Japan) fitted with hollow cathode lamp. Blank heavy metal solutions of $1000 \mathrm{ppm}$ was diluted accurately to $2.5,2,1.5,1.0,0.5,0.1$ and aspirated before analysis of digested solutions of honey samples by AOAC methods [17].

Table 1 Analytical data of physicochemical analysis of honey samples (Station: Spring; Soil: Sand)

\begin{tabular}{|c|c|c|c|c|c|c|}
\hline Location & $\begin{array}{l}\text { Sample } \\
\text { code }\end{array}$ & Moisture w/w \% & $\mathrm{pH}$ & $\begin{array}{l}\text { Acid Equivalent } \\
\mathrm{meq} / \mathrm{kg}\end{array}$ & T.D.S (ppm) & $\begin{array}{l}\text { Specific Conductivity } \\
\mu \mathrm{S} / \mathrm{cm}\end{array}$ \\
\hline Garaboli & (GR) & $(19.8-21.2) ; 20.43 \pm 0.70$ & $(4.37-4.44) ; 4.40 \pm 0.04$ & $(21-25) ; 24 \pm 0.01$ & (994 - 998); $996 \pm 2.00$ & $(1004-1007) ; 1006 \pm 1.23$ \\
\hline Balalta & (BL) & $(20.6-22.3) ; 21.4 \pm 0.85$ & $(4.36-4.40) ; 4.38 \pm 0.02$ & $(18-22) ; 24 \pm 0.21$ & $(813-816) ; 814.3 \pm 1.52$ & $(802$ - 807); $801.5 \pm 2.25$ \\
\hline Massif Street & (MS) & $(19.6-23.3) ; 20.00 \pm 0.36$ & $(4.11-4.14) ; 4.12 \pm 0.02$ & $(25-30) ; 27 \pm 0.18$ & $(644-648) ; 646 \pm 2.00$ & $(635-641) ; 638.5 \pm 3.00$ \\
\hline Rahamonat & $(\mathrm{RH})$ & $(19.8-22.3) ; 20.73 \pm 1.37$ & $(4.41-4.56) ; 4.47 \pm 0.08$ & $(22-25) ; 23 \pm 0.22$ & $(687-690) ; 688.3 \pm 1.53$ & $(677-681) ; 679.3 \pm 2.08$ \\
\hline Abanat & $(\mathrm{AB})$ & $(20.9-24.5) ; 22.93 \pm 1.84$ & $(4.20-5.39) ; 4.61 \pm 0.68$ & $(19-24) ; 22 \pm 0.45$ & $(763-766) ; 764.5 \pm 1.53$ & $(764-769) ; 767.3 \pm 2.51$ \\
\hline Al-Dawn & (AD) & $(23.4-26.7) ; 25.10 \pm 1.65$ & $(4.35-4.50) ; 4.42 \pm 0.08$ & $(21-25) ; 23 \pm 0.14$ & (835 - 839); 836.6 \pm 2.08 & (837 - 843); 841.1 \pm 3.21 \\
\hline Turhuna center & (TC) & $(22.9-24.6) ; 23.77 \pm 0.85$ & $(4.28-4.55) ; 4.37 \pm 0.15$ & $(23-27) ; 25 \pm 0.22$ & $(699-702) ; 700.3 \pm 1.53$ & $(694-698) ; 696.4 \pm 2.01$ \\
\hline Terglat & (TE) & $(21.8-24.1) ; 22.80 \pm 1.18$ & $(4.59-5.03) ; 4.74 \pm 0.25$ & $(18-22) ; 20 \pm 0.65$ & $(711-716) ; 713.3 \pm 2.51$ & (704 - 709); 707.1 \pm 2.51 \\
\hline \multicolumn{2}{|c|}{ Codex standard Limit } & $\leq 20$ & $3.2-4.5$ & $\leq 50$ & -- & $\leq 800$ \\
\hline
\end{tabular}

All values are expressed as (minimum - maximum); mean $\pm S D$

Table 2 Minerals composition of honey samples

\begin{tabular}{|c|c|c|c|c|c|c|c|}
\hline Metals & $\mathrm{Na} \mathrm{mg} / \mathrm{kg}$ & $\mathrm{K} \mathrm{mg} / \mathrm{kg}$ & Ca $\mathrm{mg} / \mathrm{kg}$ & $\mathrm{Pb} \mathrm{mg} / \mathrm{kg}$ & $\mathrm{Cd} \mathrm{mg} / \mathrm{kg}$ & $\mathrm{Hg} \mathrm{mg/kg}$ & As $\mathrm{mg} / \mathrm{kg}$ \\
\hline (GR) & $804.6 \pm 7.44$ & $1980.6 \pm 11.4$ & $1117.5 \pm 12.4$ & $7.60 \pm 0.36$ & $0.133 \pm 0.014$ & $0.056 \pm 0.01$ & $0.018 \pm 0.00$ \\
\hline (BL) & $588.4 \pm 11.3$ & $1623.1 \pm 31.3$ & $1067.5 \pm 20.7$ & $10.98 \pm 0.52$ & $0.141 \pm 0.012$ & $0.021 \pm 0.04$ & $0.014 \pm 0.01$ \\
\hline (MS) & $671.6 \pm 20.0$ & $1283.4 \pm 40.4$ & $1133.8 \pm 26.3$ & $9.61 \pm 0.45$ & $0.129 \pm 0.004$ & $0.039 \pm 0.03$ & $0.011 \pm 0.02$ \\
\hline$(\mathrm{RH})$ & $549.2 \pm 29.1$ & $1360.5 \pm 34.1$ & $1120.6 \pm 9.01$ & $3.67 \pm 0.39$ & $0.150 \pm 0.030$ & $0.098 \pm 0.02$ & $0.013 \pm 0.00$ \\
\hline$(\mathrm{AB})$ & $642 \pm 24.3$ & $1346.4 \pm 19.4$ & $1124.4 \pm 10.8$ & $5.31 \pm 0.57$ & $0.125 \pm 0.025$ & $0.081 \pm 0.02$ & $0.014 \pm 0.01$ \\
\hline (AD) & $669.9 \pm 1.03$ & $1123.4 \pm 5.73$ & $942.49 \pm 15.4$ & $6.32 \pm 0.41$ & $0.133 \pm 0.014$ & $0.048 \pm 0.01$ & $0.006 \pm 0.00$ \\
\hline (TC) & $506.8 \pm 29.2$ & $1388.1 \pm 18.9$ & $956.28 \pm 15.3$ & $2.42 \pm 0.26$ & $0.142 \pm 0.014$ & $0.014 \pm 0.03$ & $0.010 \pm 0.03$ \\
\hline (TE) & $660.1 \pm 9.83$ & $1120.1 \pm 3.01$ & $923.92 \pm 4.26$ & $8.10 \pm 1.58$ & $0.125 \pm 0.000$ & $0.100 \pm 0.04$ & $0.012 \pm 0.04$ \\
\hline
\end{tabular}

All values are expressed as (minimum - maximum); mean $\pm S D$

\section{Results and Discussion}

Table 1 shows the results of the physicochemical characterization of honey samples. The mean values of moisture content of the honey samples studied ranged from 20.0 to $25.1 \%$, These mean values are higher than the limit indicated in Codex $(\leq 20 \%)$. AD honey had the highest moisture content, while MS honey had the lowest. On the other hand, the moisture content values obtained were within the range reported by Ibrahim [18] 13.01 to $26.08 \%$. These variations in the moisture content of honey under study could may be attributed to temperature and high relative humidity of sampling location, method of honey extraction, and storage conditions.

The mean values of $(\mathrm{pH})$ were found to range between 4.12 and 4.74 . The highest $\mathrm{pH}$ value was recorded for the local honey sample that obtained from TE, while the lowest $\mathrm{pH}$ value was found in the MS sample. $\mathrm{pH}$ values of honey samples fall within the range of established Codex standard of honey 3.6 to 5.6. Also, the result shows that the mean values of acid equivalent of honey samples ranged from 20 to $27 \mathrm{meq} / \mathrm{kg}$. The results fall within the limit of international standard (lower $50 \mathrm{~m} \mathrm{eq.} / \mathrm{kg}$ ). Awad [19] mentioned a range of 16.66 to $23.34 \mathrm{meq} / \mathrm{kg}$ for the acid equivalent values of honey samples collected from west of Libya. The acidity of bee honey is due to about 18 amino acid, and other organic acids such as acetic, tartaric, ascorbic, citric, etc., particularly the gluconic acid, in equilibrium with their esters or lactones and inorganic ions such as chloride and phosphate [20].

Electrical conductivity (EC) is a best criterion of botanical origin of bee honey and today it is determined in routine honey purity and quality control [21]. The EC mean values of BL, MS, RH, AB, TC, and TE honey solutions at $25{ }^{\circ} \mathrm{C}$, were found $801,638.5,679.3,767.3,696.4$, and 707.1 $\mu \mathrm{S} / \mathrm{cm}$, respectively. These values were in agreement with British Pharmacopoeia $(\leq 800 \mu \mathrm{S} / \mathrm{cm})$ [22]. While, the higher value of EC 1006, and $841 \mu \mathrm{S} / \mathrm{cm}$ were observed in the GR, and $\mathrm{AD}$ honey solutions at $25^{\circ} \mathrm{C}$., respectively. Results agree with Gangwar et al. [23] who noted that EC of Ethiopian honey ranged from 170 to $1350 \mu \mathrm{S} / \mathrm{cm}$. Inorganic and ionic organic substances in honey samples were measured as TDS, from study the TDS of honey samples were found to be at the range of 646 to $996 \mathrm{ppm}$. The results of this study on TDS were also in agreement with the previous work of Awad [19] who reported 674 to 1256 ppm in honey collected from west of Libya. The results showed that there is a linear relationship between TDS and EC, indicating that both parameters can be used to determine honey purity.

\subsection{Mineral Composition}

The mineral composition of bee honey samples collected from GR, BL, MS, RH, AB, AD, TC, and TE were shown in Table 2 and Fig. 2 to 5 comparing the mean values of essential elements $\mathrm{Na}, \mathrm{K}$, and $\mathrm{Ca}$ obtained from bee honey samples with the values reported by Awad [19]. We could observe that the mean values range of $\mathrm{Na} 506.8$ to $804.6 \mathrm{mg} / \mathrm{kg}$, were lower than the values reported by Awad [19] 961.0 to $2110 \mathrm{mg} / \mathrm{kg}$, while the mean values range for $\mathrm{Ca}$ were the same range values reported by Awad [19] 1005 to $1414 \mathrm{mg} / \mathrm{kg}$, however, the highest concentration of calcium were reported by Girliane [24] for Brazil (jandaira) honey 1864 to $3424.9 \mathrm{mg} / \mathrm{kg}$. For honey samples the mean values for K were higher than the values reported by Awad [19] for honey samples collected from Kasr Khiar in west of Libya $1675 \mathrm{mg} / \mathrm{kg}$, also mean values of K were observed lower than the values reported by Awad [19] for honey samples collected from Garaboli in west of Libya $2466 \mathrm{mg} / \mathrm{kg}$. Saadiyah et al. [25] reported that the potassium content in Brazil (jandaira) honey samples ranged from 5918.5 to $13366.6 \mathrm{mg} / \mathrm{kg}$. The essential metals $\mathrm{Na}, \mathrm{K}$, and $\mathrm{Ca}$ can also produce toxic effects when the metal intake is excessively increased.

Fig. 2 shows that the major elements are in the order $\mathrm{K}>\mathrm{Ca}>\mathrm{Na}$ for honey samples. The high concentration of potassium in bee honey samples can be attributed to the high levels of potassium ions in plant tissues.

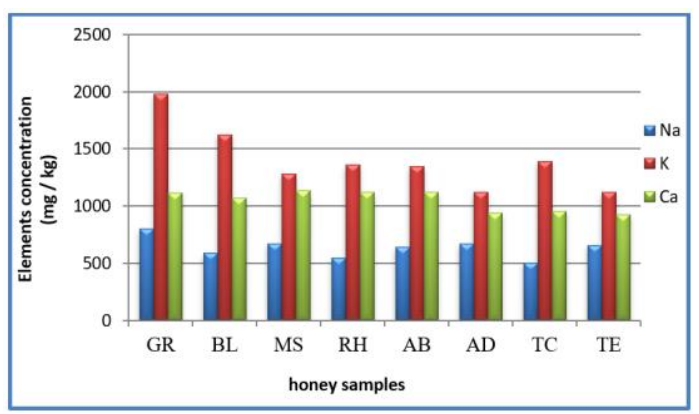

Fig. 2 Distribution of sodium, potassium, and calcium in honey samples

The toxic elements $\mathrm{Pb}, \mathrm{Cd}, \mathrm{Hg}$, and As are industrial pollutants which have high negative effect on human and animal health. Soils, rocks, weather conditions, and mineral fertilizers, contain slight amount of toxic 
heavy metals, and they effect on the final level of $\mathrm{Pb}, \mathrm{Cd}, \mathrm{Hg}$, and As concentration in a plant.

Table 2 and Fig. 3 show that the mean values of $\mathrm{Pb}$ in honey samples collected from GR, BL, MS, RH, AB, AD, TC, and TE were 7.6, 10.98, 9.61, $3.67,5.31,6.32,2.42$, and $8.1 \mathrm{mg} / \mathrm{kg}$, respectively, and were clear higher than the values reported by Codex (less than $0.1 \mathrm{mg} / \mathrm{kg}$ ), Poland standards, however it is reported that maximum $\mathrm{Pb}$ levels in honey samples as $0.5 \mathrm{mg} / \mathrm{kg}$ [26], and in the European Union Member States the maximum $\mathrm{Pb}$ levels in honey samples as $1.0 \mathrm{mg} / \mathrm{kg}$ [27]. When comparing the mean values range of $\mathrm{Pb}$ content determined in the current study with the Argentina Australia and Brazil honey, the higher range of $\mathrm{Pb}$ concentration appeared in Argentina Australia and Brazil honey samples 115.17 to $332.33 \mathrm{mg} / \mathrm{kg}$, while $\mathrm{Pb}$ values in the Egyptian honey range from 4.12 to $9.3 \mathrm{mg} / \mathrm{kg}$. Saadiyah et al. [25] reported that the $\mathrm{Pb}$ content in Turkey honey ranged from 8.4 to $44.1 \mathrm{mg} / \mathrm{kg}$. High concentration of $\mathrm{Pb}$ ions in bee honey described in other studies may indicate a possible environmental pollution, as revealed by Lambert et al. [28].

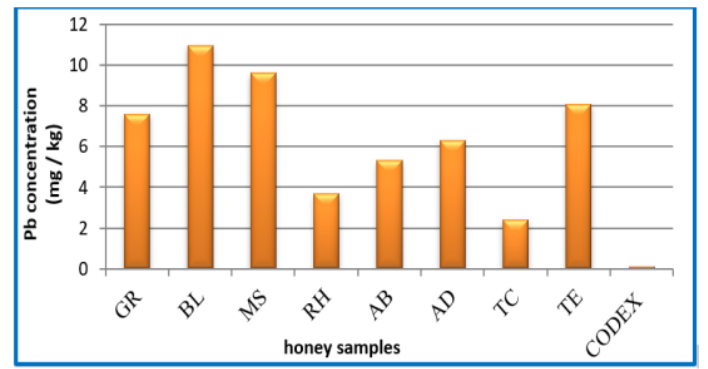

Fig. 3 Distribution of Lead metal in honey samples

From Fig. 4, it can be seen that the mean values of $\mathrm{Cd}$ in honey samples fall in the range of 0.125 to $0.150 \mathrm{mg} / \mathrm{kg}$. The results show there is no differences in the concentration of $\mathrm{Cd}$ in any samples, these results were similar to that reported by Rashed and Soltan [29] for Egyptian honey 0.1 to $0.5 \mathrm{mg} / \mathrm{kg}$, and Saadiyah et al. [25] for Saudi Arabia honey 0.1 to 0.16 $\mathrm{mg} / \mathrm{kg}$, but a little higher than the value reported by standard codex limit $0.05 \mathrm{mg} / \mathrm{kg}$.

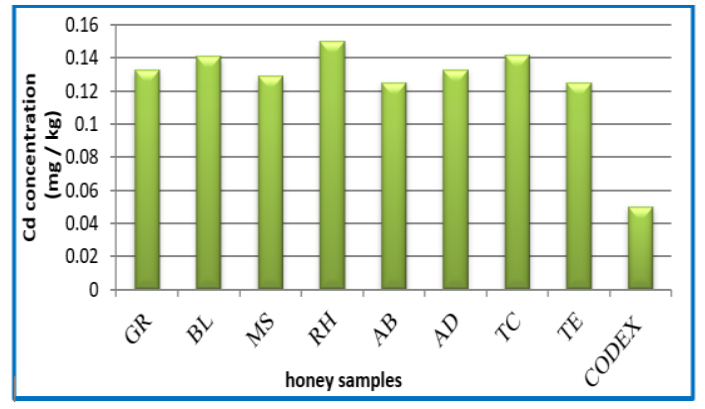

Fig. 4 Distribution of cadmium metal in honey samples

Table 2 and Fig. 5 show that the mean values of mercury (Hg), and Arsenic (As) in honey samples were ranged from 0.021 to 0.10 , and 0.006 to $0.018 \mathrm{mg} / \mathrm{kg}$, respectively. These values were below the sensitive detection limit of Codex.

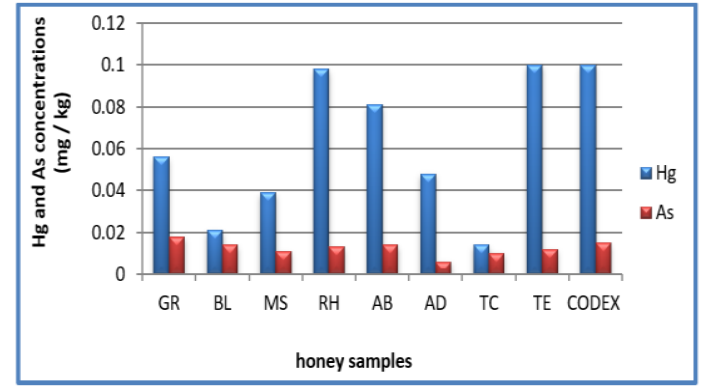

Fig. 5 Distribution of mercury, and arsenic metals in honey samples

\section{Conclusion}

The results of this study clearly show that bee honey samples collected from eight locations in west of Libya have good physicochemical properties and high concentration of essential elements and may be considered as a source of these elements to human body when taken freshly in crude form or manufactured in honey product. The Libyan honey samples collected from west of Libya tend to have higher average content of $\mathrm{Pb}$ and $\mathrm{Cd}$, whereas, the $\mathrm{BL}$ samples tend to have higher content of $\mathrm{Pb}$ metals. The data also shows that toxic heavy elements such as $\mathrm{Hg}$, and As are present as traces.

\section{Acknowledgement}

The authors would like to thank The Libyan Authority for Research, Science and Technology, and Al-Mergib University, Faculty of Art and Science Kasr Khiar, Libya, for their greatly appreciate support this study.

\section{References}

[1] Codex, Honey codex alimentarius commission, FAO/WHO, 1994

[2] FDA, Food and Drug Administration, National Honey Board, USA, 2007.

[3] D. Anupama, K.K. Bhat, V.K. Sapna, Sensory and physicochemical properties of commercial samples of honey, Food Res. Int. 36 (2003) 183-191.

[4] A.J. Braziewicz, B.I. Fijal, B.C. zewski, B.M. Jaskola, A.D. Banas, et al., PIXE and XRF analysis of honey samples, Nucl. Instr. Method. Phys. Res. B 187 (2002) 231-237.

[5] H.D. John, "Heavy Metals" - A meaningless term, Pure Appl. Chem. 74 (2002) 793-807.

[6] A. Mbiri, A. Onditi, N. Oyaro, E. Murago, Determination of essential and heavy metals in kenyan honey by atomic absorption and emission spectroscopy, Jour. Agri. Sci. Tech. 13(1) (2011) 107-116.

[7] J.W. White, W.D. Landis, Honey composition and properties, beekeeping in the US agriculture handbook, DC: US, Department of Agriculture Technical Bulletin, Washington, 1980.

[8] O.M. Herna, J.M. Fraga, A.I. Jimenez, F. Jimenez, J.J. Arias, Characterization of honey from the Canary Islands: Determination of the mineral content by atomic absorption spectrophotometer, Food Chem. 93 (2005) 449-458.

[9] M. Mohammed, A.Z. Muhammed, A.R. Mohammad, A.S. Siti, H.G. Siew Determination of mineral, trace element, and pesticide levels in honey samples originating from different regions of Malaysia compared to Manuka honey, Bio. Med. Res. Int. 1 (2014) 1-10.

[10] L.W. David, Trace elements and neuropsychological problems as reflected in tissue mineral analysis (TMA) patients, J. Orthomol. Med. 5(3) (1990) 159-160.

[11] H.L. House, Insect Nutrition, Ann. Rev. Entoml. 6 (1961) 13-26.

[12] G.A. Grigoryan, V.A. Stepanyan, A.A. Markosyan, Trace elements in pollen pellets and in the body of bees, Proc. Int Apic. Congr. Moscow 23 (1971) 425431.

[13] M.H. Haydak, L.S. Palmer, M.C. Tanquary, A.E. Vivino, The effect of commercial clarification on the vitamin content of honey, Jour. Nutr. 26 (1942) 319321.

[14] M. Eyobel, A. Wodaje, B. Lemessa, T. Miresa, Physicochemical characterization and pesticide residue analysis of honey produced in West Shewa Zone, Oromia Region, Ethiopia, Am. J. Appl. Chem. 5(6) (2017) 101-109.

[15] O. Olugbemi, C.H. Ikeme, I.J. Dioha, Physicochemical analysis of honey from Umuahia, Abia state, Nigeria, Res. J. Eng. Appl. Sci. 2(3) (2002) 199-202.

[16] AOAC, Official Methods of Analysis, $16^{\text {th }}$ Edn., Association of Official Analytical Chemists, Washington, DC., 1999.

[17] AOAC, Official methods of analysis, $12^{\text {th }}$ Edn., Association of Official Analytical Chemists, Washington, DC, 1995

[18] A.O. Ibrahim, Studies on Sudanese honeys, M.Sc. Thesis, Faculty of Agriculture, University of Khartoum, Sudan, 1985.

[19] M.H. Awad, M.E. Aborawi, Physicochemical characterization of honey from Kasr Khiar and Garaboli areas-Libya, Asian J. Plant Sci. Res. 6(1) (2016) 8-12.

[20] J. Mojca, B. Jasna, G. Terezija, Linear regression model of the ash mass fraction and electrical conductivity for Slovenian honey, Food Technol. Biotechnol. Slovenia 3 (2008) 335-340.

[21] Y. Desissa, Detection of the Electrical conductivity and acidity of honey from different areas of Tepi, Food Sci. Technol. 2(5) (2014) 59-63.

[22] British Pharmacopoeia, Monographs: medicinal and pharmaceutical substances honey, MHRA, London, 1-2 (2009) $2969-2973$.

[23] S.K. Gangwar, H. Gebremariam, A. Ebrahim, S. Tajebe, Characteristics of honey produced by different plant species in Ethiopia. Adv. Biores. 1 (2010) 101-105

[24] R. Girliane, Da Silva, Identification of sugar, amino acids and minerals from the pollen of Jandaira stingless bees (Melipona subnitida), Food Nutr. Sci. 5 (2014) 1015-1021.

[25] A.D. Saadiyah, H.H. Ameera, Determination of Heavy metals and trace element levels in honey samples from different regions of Iraq and compared with other kind, Am. J. Appl. Chem. 3(3) (2015) 83-92.

[26] F. Karaman, L. Martin, Heavy metal in finish honey, Apiacta 35 (2000) 85-95.

[27] S. Bogdanov, B. Zimmerli, M. Erard, Heavy metals in honey, Mitt Gebiete Lebensm 77 (1985) 153-158.

[28] O. Lambert, M. Piroux, S. Puyo, C. Thorin, M. Larhantec, F. Delbac, H. Pouliquend Bees, honey and pollen as sentinels for lead environmental contamination, Environ. Pollut. 170 (2012) 254-259.

29] M. Rashed, M. Soltan, Major and trace elements in different types of Egyptian mono-flora and non-flora bee honeys, Jour. Food Comp. Anal. 17 (2004) 725735. 